\title{
Modelling and Experimental Validation of a VNT Turbocharger for Improving Performances of a Marine Diesel Generator Engine
}

\section{Modeliranje i eksperimentalna validacija turbopuhala promjenjive geometrije za poboljšanje performansi brodskog motora s dizel generatorom}

\author{
Nguyen Quang Vinh \\ Ho Chi Minh City University of Transport \\ Viet Nam \\ e-mail: quangvinh2802@gmail.com
}

\author{
Bui Hong Duong \\ Ho Chi Minh City University of Transport \\ Viet Nam \\ e-mail: bhduongin@gmail.com
}

\author{
Le Van Vang \\ Ho Chi Minh City University of Transport \\ Viet Nam \\ e-mail: levanvang@gmail.com
}

\author{
DOI 10.17818/NM/2020/2.2 \\ UDK 621.313.1:004.4 \\ 621.436:629.5 \\ Original scientific paper / Izvorni znanstveni rad \\ Paper accepted / Rukopis primljen: 1. 1. 2020.
}

\section{Summary}

This paper presents modelling and experimental validation for improving the performances of a marine diesel generator engine. Based on the diesel engine theory, the laws of conservation of energy, and the principle of movement of flow through turbocharger nozzle, a mathematical model of a real turbocharged engine was built, concentrating on the mathematic model of flow through nozzles. This model is simulated by Matlab/Simulink program, the results of simulation showed the relationships between the engine and the turbocharger, the turbine and the compressor, and between the nozzles and the turbocharger. The experiments were carried out to validate this model, the errors between the simulation and measure were acceptable. The measure and simulation results also determined that at the low load conditions ( $\leq 50 \%$ load) engine performances can be improved by adjusting nozzle opening degree (from fully opening to $90 \%$ and $80 \%$ opening).

\section{Sažetak}

Ovaj rad prikazuje modeliranje i eksperimentalnu validaciju za poboljšanje performansi brodskog motora s dizel generatorom. Na temelju teorije dizel motora, zakona očuvanja energije i načela kretanja protoka kroz mlaznicu turbopuhala izrađen je matematički model pravog motora s turbopunjenjem, s fokusom na matematičkom modelu protoka kroz mlaznice. Ovaj model je simuliran programom Matlab / Simulink, a rezultati simulacije pokazali su odnos motora i turbopuhala, turbine $i$ kompresora, te mlaznica i turbopuhala. Eksperimenti su provedeni kako bi se provjerio ovaj model, a pogreške između simulacije i mjere bile su prihvatljive. Rezultati mjerenja i simulacije također su odredili da se pri uvjetima malog opterećenja ( $\leq 50 \%$ opterećenja) performanse motora mogu poboljšati podešavanjem stupnja otvaranja mlaznica (od potpunog otvaranja do $90 \%$ i $80 \%$ otvaranja).

\section{KEY WORDS}

variable nozzle turbine,

turbocharger

engine performance

diesel generator engine

\section{INTRODUCTION / UVOD}

The turbocharger has been developed steadily since the 1940s [1] and achieved great results. Nowadays, many manufacturers and universities are studying advanced performances of the turbocharger besides reducing emissions. Variable nozzle turbines are applied widely such as in passenger transport, marine, railway, etc. Reality has proved its effectiveness, including transient response, over-boosting prevention, and improved low load condition characteristics.

Marine diesel generator engines usually operate at a constant speed with a wide range of loads. At medium and high load conditions, the amount of gas provided is enough for diesel engines, however, at lower load conditions, the turbocharger speed becomes slowly, the intake pressure is decreased, and diesel engines usually operate in lack of fresh air condition, called "black smoke situation". Besides that, for old engines, after a long time of use, due to leakage, incomplete combustion, a larger amount of air needs to be provided; therefore the speed of the turbine needs to be improved. Many solutions that have been executed, and in this paper a method to solve this problem is also presented.

The integrated study of theory and experiment is a useful method to improve the mathematic models based on the correction of some coefficients via the experiment database. Many scientists have researched and built models that simulate 
turbocharged diesel engines. The theories of the engine model have been studied by R.S. Benson and N.D Whitehouse [2], J. Heywood [3]. The heat release model of Weibe [4] and the heat transfer model of Woschni [5] have been widely used to analyze and model the engine working processes. Colin R.Ferguson and Allan T.Kirkpatrick in their research [6] based on the mean value engine model and thermodynamic laws to build models of the internal combustion engine, the simple simulations showed results with high reliability.

The theory of VNT was studied at the end of the $20^{\text {th }}$ century, Watson and Janota [1] built key equations for modeling and simulating. Franklin [7] presented the highlighting performances of VNT which was better than the fixed one. In the early $21^{\text {st }}$ century, Lars Eriksson et al. [8] built the mean value model of VNT turbocharger and evaluated the influences of nozzle opening degree to engine performances. Yasuaki Jinnai et al. [9] analyzed structures and performances of the turbocharger by CFD simulation, developed a new design of the turbocharger which met the regulations of emissions and increased aerodynamics and reliability, low cost, productivity efficiency. Additionally, many experiments were carried out to evaluate the effectiveness of VNT technology by the researcher and sponsor Holset, Garrett, MHI...

The aim of this paper is to analyze the relationship and interaction among components, including a marine diesel generator engine and its turbocharger, which clearly describes the working processes of a sample engine installed on a ship. The main model and sub-models are built to describe these relationships. The modelling was validated by experiments at the laboratory of Viet Nam Maritime University (VMU). The modelling and experiments also determined the optimization of the nozzle opening degrees at the low load conditions $(\leq 50 \%)$. It is possible to improve engine performances with narrower nozzle opening degree, especially for old engines. The other purpose of the simulation program is to build ourselves a tool for researching, training and improving the engine's working characteristics

\section{MATHEMATICAL MODEL / Matematički model}

\subsection{Engine model / Model motora}

Engine performance parameters / Parametri performansi motora

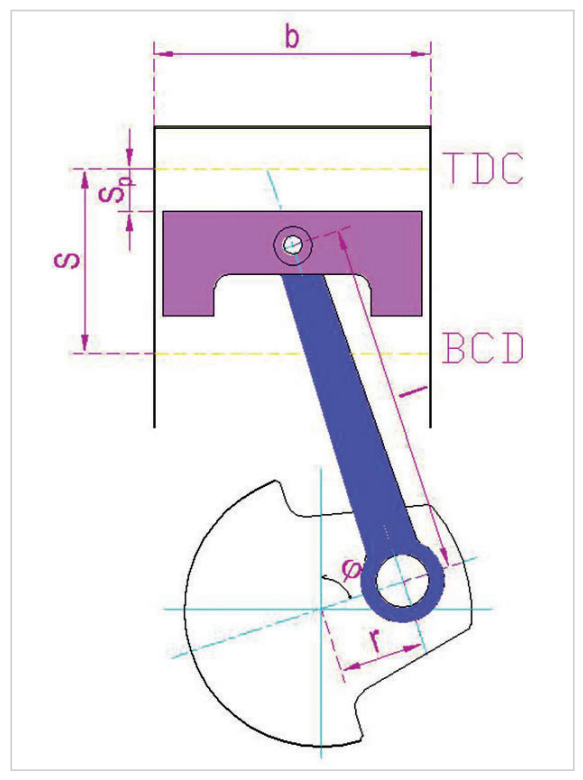

Figure 1 Engine performance

Slika 1. Performanse motora
Assuming that crank angle $\varphi=0$ when the piston at the top dead centre (TDC), the dimensionless instantaneous stroke is:

$$
\overline{\mathrm{s}}_{\mathrm{p}}=\frac{\mathrm{s}_{\mathrm{p}}}{\mathrm{s}}=\frac{1}{2}(1-\cos \varphi)+\frac{1}{2 \mathrm{e}}\left[1-\left(1-\mathrm{e}^{2} \sin ^{2} \varphi\right)^{1 / 2}\right]
$$

Where, $s(m)$ is the distance between the top dead centre (TDC) and the bottom dead centre (BDC); $s_{p}(m)$ is the instantaneous stroke, e (-) is the ratio of the crankshaft radius $r$ $(\mathrm{m})$ to the connecting rod length $\mathrm{I}(\mathrm{m}), \mathrm{e}=\mathrm{r} / \mathrm{l}$.

The Instantaneous volume displacement $\mathrm{V}_{d}(\varphi)$ is:

$$
\mathrm{V}_{\mathrm{d}}(\varphi)=\pi \cdot \mathrm{b}^{2} \cdot \mathrm{s}_{\mathrm{p}} / 4
$$

Where, $b(m)$ is the bore of a cylinder

Dimensionless instantaneous cylinder volume:

$$
\overline{\mathrm{V}}_{\mathrm{d}}=\frac{\mathrm{V}_{\mathrm{d}}(\varphi)}{\mathrm{V}_{\mathrm{a}}}=\frac{1}{\varepsilon}\left[1+\frac{\varepsilon-1}{2}(1-\cos \varphi)+\frac{1}{2 \mathrm{e}}\left[1-\left(1-\mathrm{e}^{2} \sin ^{2} \varphi\right)^{1 / 2}\right]\right]
$$

Where $V_{a}\left(m^{3}\right)$ is cylinder volume when piston at BDC, $\varepsilon(-)$ is the compression ratio; e $(-)$ is the ratio of the crankshaft radius $r$ $(\mathrm{m})$ to the connecting rod length $\mathrm{I}(\mathrm{m}), \mathrm{e}=\mathrm{r} / \mathrm{l}$.

\section{Heat release / Otpuštanje topline}

The total low heat value LHV $(\mathrm{kJ} / \mathrm{kg})$, which provide for a cycle, is calculated as

$$
\mathrm{Q}_{\text {in }}=\frac{\mathrm{LHV}^{*} \mathrm{~m}_{\text {air }}}{\mathrm{AFR}}
$$

Where LHV $(\mathrm{kJ} / \mathrm{kg})$ is the low heat value of fuel, $\mathrm{m}_{\text {air }}(\mathrm{kh})$ is the amount of air in a cycle, AFR(-) is the air/fuel ratio.

The increment heat $\partial Q_{\text {in }}$ is calculated as:

$$
\frac{\partial \mathrm{Q}_{\text {in }}}{\mathrm{d} \varphi}=\mathrm{Q}_{\text {in }} \frac{\mathrm{dx}}{\mathrm{d} \varphi}
$$

Where the cumulative burn fraction of fuel $(x)$ is based on double Weibe's formula $[4,10]$

$$
\begin{aligned}
& \frac{\mathrm{dx}}{\mathrm{d} \varphi}=\frac{\mathrm{dx}_{1}}{\mathrm{~d} \varphi}+\frac{\mathrm{dx}}{\mathrm{d} \varphi} \\
& \frac{\mathrm{dx}_{1}}{\mathrm{~d} \varphi}=\beta \cdot \mathrm{a}\left(\mathrm{m}_{\mathrm{p}}+1\right) \frac{1}{\varphi_{\mathrm{p}}}\left(\frac{\varphi-\varphi_{\mathrm{s}}}{\varphi_{\mathrm{p}}}\right)^{-\mathrm{a}\left(\frac{\varphi-\varphi_{\mathrm{s}}}{\varphi_{\mathrm{p}}}\right)^{\mathrm{m}_{\mathrm{p}}+1}} \\
& \frac{\mathrm{dx}_{2}}{\mathrm{~d} \varphi}=(1-\beta) \cdot \mathrm{a}\left(\mathrm{m}_{\mathrm{d}}+1\right) \frac{1}{\varphi_{\mathrm{d}}}\left(\frac{\varphi-\varphi_{\mathrm{s}}}{\varphi_{\mathrm{d}}}\right)^{-\mathrm{a}\left(\frac{\varphi-\varphi_{\mathrm{s}}}{\varphi_{\mathrm{d}}}\right)^{\mathrm{m}_{\mathrm{p}}+1}}
\end{aligned}
$$

Where $d x / d \varphi$ is the combustion law; $d x_{1} / d \varphi$ is the premix combustion law; $\mathrm{dx}_{2} / \mathrm{d} \varphi$ is the di-ffusion combustion law; $a$ is the Weibe efficiency factor; $m_{p}$ the is premix combustion quality factor; $m_{d}$ is the diffusion combustion quality factor; $\varphi_{s}$ is the start of combustion; $\varphi_{p}$ is the duration of premix combustion; $\varphi_{d}$ is the duration of diffusion combustion; $\beta$ is the ratio of the amount of fuel burning in premix combustion phase to the total.

\section{Heat loss / Gubitak topline}

The heat transfer through the surrounded wall of combustion chamber $\partial \mathrm{Q}_{\text {loss }}$ is calculated as [6] :

$$
\frac{\partial Q_{\text {loss }}}{d \varphi}=h_{g}(\varphi) A_{w}(\varphi)\left(T-T_{w}\right) / n_{e}
$$

Where, $T\left({ }^{0} \mathrm{~K}\right)$ is the instantaneous bulk gas temperature; $T_{w}\left({ }^{\circ} \mathrm{K}\right)$ is the mean temperature of cylinder wall; $A_{w}(\varphi)\left(m^{3}\right)$ is the area of combustion chamber surface, $n_{e}$ is the engine speed (rev/min); and $h_{g}\left(\mathrm{~W} / \mathrm{m}^{2} . \mathrm{K}\right)$ is the Woschni heat transfer coefficient which is calculated as follows:

$$
\mathrm{h}_{\mathrm{g}}=3,26 \mathrm{p}^{0.8} \mathrm{U}^{0.8} \mathrm{~b}^{-0.2} \mathrm{~T}^{-0.55}
$$


Where $\mathrm{b}(\mathrm{m})$ is the cylinder bore; $\mathrm{U}(\mathrm{m} / \mathrm{s})$ is the heat transfer rate which follows Woschni's equation:

$$
\mathrm{U}=2.28 \overline{\mathrm{v}}_{\mathrm{p}}+0.00324 \frac{\mathrm{V}_{\mathrm{d}} \mathrm{T}_{\mathrm{a}}}{\mathrm{p}_{\mathrm{a}} \mathrm{V}_{\mathrm{a}}} \mathrm{p}
$$

Where $T_{a}\left({ }^{0} \mathrm{~K}\right)$ and $\mathrm{p}_{\mathrm{a}}\left(\mathrm{N} / \mathrm{m}^{2}\right)$ are the temperature and pressure at the end of the charging process, respectively. $\bar{v}_{p}$ is mean piston speed $(\mathrm{m} / \mathrm{s}), \mathrm{V}_{d}\left(\mathrm{~m}^{3}\right)$ is the displacement volume, $\mathrm{V}_{\mathrm{a}}\left(\mathrm{m}^{3}\right)$ is cylinder volume when piston at BDC.

\section{The First law of thermodynamics / Prvi zakon termodinamike}

Building a simulation of the process of a diesel engine is certainly a complicated job. In this paper, the First law of Thermodynamics is used to build this model, with the assumption that the intake and the exhaust processes are of isentropic processes and the exhaust gas is expelled to a constant pressure chamber. The compression, combustion and expansion processes include the processes of heat release, heat transfer as shown in the following heat balance differential equation:

$$
\frac{\partial Q_{\text {in }}}{d \varphi}-\frac{\partial Q_{\text {loss }}}{d \varphi}-p \frac{d V}{d \varphi}=m c_{v} \frac{d T}{d \varphi}+c_{v} T \frac{d m}{d \varphi}
$$

Where $c_{v}(\mathrm{~J} / \mathrm{kg} . \mathrm{K})$ is the specific heat capacity at constant volume.

From the equation of gas state $\mathrm{pV}=\mathrm{mRT}$, which in differential form is:

$$
\mathrm{mdT}=\frac{1}{\mathrm{R}}(\mathrm{pdV}+\mathrm{Vdp})
$$

To combine equation (12) with equation (13), the differential equation of cylinder pressure varying with the crank angle is written as follows:

$$
\begin{aligned}
& \frac{\mathrm{dp}}{\mathrm{d} \varphi}=-\mathrm{k} \frac{\mathrm{p}}{\mathrm{V}} \frac{\mathrm{dV}}{\mathrm{d} \varphi}+\frac{\mathrm{k}-1}{\mathrm{~V}} \frac{\partial \mathrm{Q}_{\text {in }}}{\mathrm{d} \varphi}-\frac{\mathrm{k}-1}{\mathrm{~V}} \frac{\partial \mathrm{Q}_{\text {loss }}}{\mathrm{d} \varphi} \\
& \text { Where } \mathrm{k}(-) \text { is the gas constant }\left(\mathrm{c}_{\mathrm{p}} / \mathrm{c}_{\mathrm{v}}\right) .
\end{aligned}
$$

\subsection{Turbocharger model / Model turbopuhala}

The Simulink model of the turbocharger is described as Figure 2, which includes three main blocks: Turbine block, Compressor blocks and balance block.

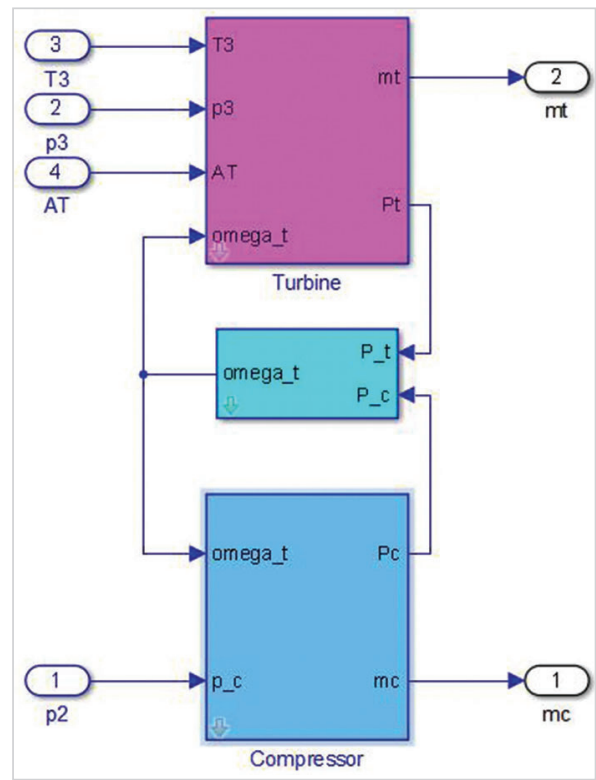

Figure 2 Turbocharger model in Simulink Slika 2. Model turbopuhala u Simulinku

\subsubsection{Turbine model / Model turbine}

\section{Mass flow model / Model masenog protoka}

The performance of a turbocharger can be described by mass flow rate $\dot{\mathrm{m}}_{\mathrm{t}}(\mathrm{kg} / \mathrm{min})$ and pressure ratio $\pi_{\mathrm{t}}(-)$. The mass flow rate is limited at high pressure ratio $\left(1 / \pi_{t}\right)$ by the choking line (when the intake flow velocity reaches the velocity of sound).

Turbine mass flow depends on the area that the flow goes through it $[8,11]$, it can be expressed as equation (15)

$$
\dot{\mathrm{m}}_{\mathrm{t}}=\mathrm{A}_{\mathrm{Tmax}} \frac{\mathrm{p}_{3}}{\sqrt{\mathrm{R}_{\mathrm{e}} \mathrm{T}_{3}}} \mathrm{f}_{\pi_{\mathrm{t}}}\left(\pi_{\mathrm{t}}\right) \mathrm{f}\left(\mathrm{A}_{\mathrm{T}}\right)
$$

Where, $\dot{\mathrm{m}}_{\mathrm{t}}$ is the mass flow through the nozzle $(\mathrm{kg} / \mathrm{s}) ; \mathrm{R}_{\mathrm{e}}$ is the exhaust gas constant $(\mathrm{J} / \mathrm{kg} \cdot \mathrm{K})$

$A_{T}$ is the area of the nozzles $\left(m^{2}\right), A_{T \max }$ is the maximum of $A_{T}$ $\left(\mathrm{m}^{2}\right) ; \mathrm{p}_{3}\left(\mathrm{~N} / \mathrm{m}^{2}\right), \mathrm{T}_{3}(\mathrm{~K})$ are the pressure and temperature in the exhaust manifold (before turbine); $\pi_{t}$ is pressure ratio (-).

\section{Sub-Model $f\left(\pi_{t}\right)$ and $f\left(A_{t}\right)$ :}

Sub-model $f\left(\pi_{t}\right): f\left(\pi_{t}\right)$ is the sub model uses to describe the pressure ratio after and before turbine $\pi \mathrm{t}(\pi \mathrm{t}=\mathrm{p} 4 / \mathrm{p} 3)$.

Figure 4 presents a sketch of the turbocharger balance. With $\mathrm{p}_{3}\left(\mathrm{~N} / \mathrm{m}^{2}\right)$ is the pressure in the manifold before the turbine, $\mathrm{p}_{4}$ is the pressure after the turbine $\left(\mathrm{N} / \mathrm{m}^{2}\right)$. Because of $\mathrm{p}_{4}<\mathrm{p}_{3^{\prime}}$, so that $0<\pi_{t}<1$. As the pressure ratio $\pi_{t}$ decreases, the corrected mass flow increases until the gas reaches the sonic condition and the flow is choked. We can use the sub-model $\pi_{t}$ to describe it as follows [12]:

$$
\mathrm{f}\left(\pi_{\mathrm{t}}\right)=\sqrt{1-\pi_{\mathrm{t}}^{\mathrm{k}_{\mathrm{e}}}}
$$

Where $k_{e}$ is specific heat capacity ratio of exhaust gas $\left(k_{e}=c_{p} / c_{v}\right)$.

Sub-model $f\left(A_{T}\right)$ : To describe the behaviour of nozzles, we use the sub-model $A_{\text {eff }}\left(A_{\text {eff }}\right.$ is the cross-section of nozzles)

$$
A_{\text {eff }}=A_{\text {Tmax. }} f\left(A_{T}\right)
$$

According to Lars Eriksson et al [11] , the equation $f\left(A_{T}\right)$ can be described by the part of an ellipse:

$$
\left[\frac{\mathrm{f}\left(\mathrm{A}_{\mathrm{T}}\right)-\mathrm{c}_{1}}{\mathrm{c}_{2}}\right]^{2}+\left[\frac{\mathrm{A}_{\mathrm{T}}-\mathrm{c}_{3}}{\mathrm{c}_{4}}\right]^{2}=1
$$

Where $c_{1}, c_{2}, c_{3}, c_{4}$ are tuning parameters.

\section{Turbine efficiency model / Model učinkovitosti turbine}

According to Watson and Janota [1], the relationship between the turbine efficiency and blade speed ratio (BSR) can be described as a parabolic function.

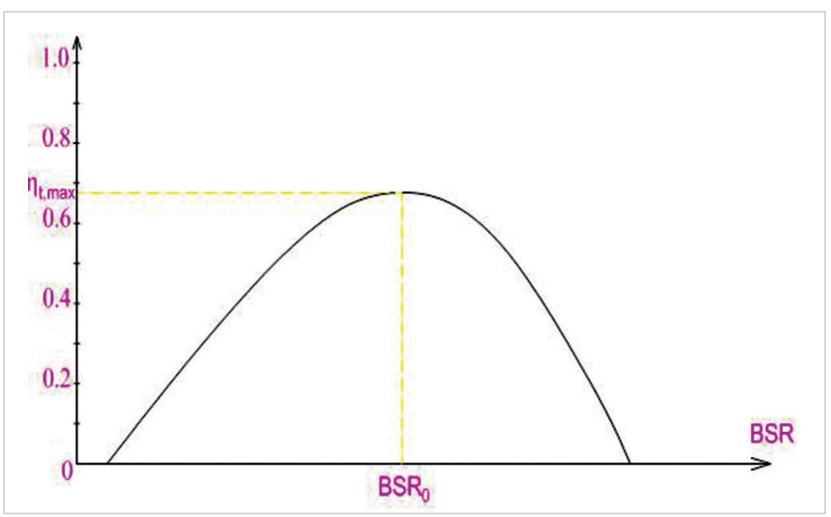

Figure 3 Turbine efficiency against blade speed ratio (BSR) [1] Slika 3. Učinkovitost turbine u odnosu na brzinu lopatice (BSR) [1] 
Therefore, the turbine efficiency can be expressed as below

$\eta_{\mathrm{t}}=\eta_{\mathrm{t}, \text { max }}-\mathrm{a}_{1}\left(\mathrm{BSR}-\mathrm{BSR}_{0}\right)^{2}-\mathrm{a}_{2}\left(\mathrm{BSR}-\mathrm{BSR}_{0}\right)^{2}-\mathrm{a}_{3}$

Where, $\eta_{t, \text { max }}$ is the maximum of turbine efficiency, $B S R_{0}$ is the optimum of blade speed $\left(a t \eta_{t, m a x}\right), a_{1^{\prime}} a_{2^{\prime}} a_{3}$ are the tuning parameters.

The effective turbine power model / Model učinkovitosti turbine Due to the expansion of the exhaust gas on the turbine blade, the effective turbine power depends on the mass flow rate of gas and enthalpy drop in the turbine. It resulted as [1]

$$
\mathrm{P}_{\mathrm{t}}=\eta_{\mathrm{t}} \dot{\mathrm{m}}_{\mathrm{t}} \mathrm{c}_{\mathrm{pe}} \mathrm{T}_{3}\left(1-\pi_{\mathrm{t}}^{1-\frac{1}{\mathrm{k}_{\mathrm{e}}}}\right)
$$

Where, $\eta_{t}$ is the turbine efficiency; $\dot{m}_{t}$ is the flow rate $(\mathrm{kg} / \mathrm{s})$; $\mathrm{C}_{\mathrm{pe}}$ is the specific heat capacity at constant pressure $(\mathrm{J} / \mathrm{kg} \cdot \mathrm{K}) ; \mathrm{T}_{3}$ is the temperature of the exhaust gas before the turbine $(K) ; k_{e}$ is specific heat capacity ratio of exhaust gas $\left(k_{e}=c_{p} / c_{v}\right)$

\subsubsection{Compressor model / Model kompresora} Compressor efficiency model / Model učinkovitosti kompresora The real compression process in the compressor is the polytropic process due to friction and losses in the compressor. According to [13] the compressor efficiency can be written in terms of temperature and pressure ratio as below

$$
c_{\mathrm{c}}=\frac{\mathrm{T}_{1}\left(\pi_{\mathrm{c}}^{\frac{\mathrm{k}_{\mathrm{a}}-1}{\mathrm{k}_{\mathrm{a}}}}-1\right)}{\mathrm{T}_{2}-\mathrm{T}_{1}}
$$

Where $T_{1}, T_{2}$ are the pressures before and after of the compressor $(\mathrm{K}), \mathrm{k}_{\mathrm{a}}(-)$ is the specific heat capacity ratio of intake air $\left(\mathrm{k}_{\mathrm{a}}=\mathrm{c}_{\mathrm{pa}} / \mathrm{c}_{\mathrm{va}}\right) ; \pi_{\mathrm{c}}(-)$ is the pressure ratio after and before of the compressor $\left(\mathrm{p}_{2} / \mathrm{p}_{1}\right)$.

\section{Compressor mass flow model / Model masenog protoka kompresora}

The compressor mass flow $\left(\dot{\mathrm{m}}_{\mathrm{c}}\right)$ is modelled using two dimensionless parameters [8] as below

$$
\begin{gathered}
\Psi=\frac{\mathrm{c}_{\mathrm{pa}} \mathrm{T}_{1}\left(\pi_{\mathrm{c}}^{\frac{\gamma_{\mathrm{a}}-1}{\gamma_{\mathrm{a}}}}-1\right)}{\mathrm{n}_{\mathrm{t}}^{2} \mathrm{D}_{\mathrm{t}}^{2}} \\
\Phi=\frac{\dot{\mathrm{m}}_{\mathrm{c}}}{\mathrm{n}_{\mathrm{t}} \mathrm{D}_{\mathrm{t}}^{3}} \frac{\mathrm{R}_{\mathrm{a}} \mathrm{T}_{1}}{\mathrm{p}_{1}}
\end{gathered}
$$

Where, $c_{p a}(J / k g . K)$ is the specific heat at the constant pressure of the intake air; $R_{a}(J / k g . K)$ is the gas constant; $\pi_{c}(-)$ is the pressure ratio; $p_{1}\left(N / \mathrm{m}^{2}\right), T_{1}(K)$ are the ambient pressure and temperature; $n_{t}(r e v / \mathrm{min})$ is the turbine speed; $D_{t}(m)$ is the diameter of the turbine blade.

According to Sorenson et al.[14], the relationship between $\Phi$ and $\Psi$ is

$$
\Phi=\mathrm{k}_{0}-\mathrm{k}_{1} \frac{\Psi}{\eta_{\mathrm{c}}}
$$

Where, $\mathrm{k}_{0}, \mathrm{k}_{1}$ are the tuning parameters; $\eta_{c}$ is the compressor efficiency determined by (21).

Therefore, from (23) the mass flow of compressor is calculated as

$$
\dot{\mathrm{m}}_{\mathrm{c}}=\Phi \mathrm{n}_{\mathrm{t}} \mathrm{D}_{\mathrm{t}}^{3} \frac{\mathrm{p}_{1}}{\mathrm{R}_{\mathrm{a}} \mathrm{T}_{1}}
$$

\section{Compressor power model / Model snage kompresora}

Compressor power can be described by mass flow, temperature, pressure as in [1]

$$
\mathrm{P}_{\mathrm{c}}=\frac{1}{\eta_{\mathrm{c}}} \dot{\mathrm{m}}_{\mathrm{c}} \mathrm{c}_{\mathrm{pa}} \mathrm{T}_{1}\left(\pi_{\mathrm{c}}^{\frac{\mathrm{k}_{\mathrm{a}}-1}{\mathrm{k}_{\mathrm{a}}}}-1\right)
$$

Where, $\eta_{c}$ is the compressor efficiency; $\dot{m}_{c}$ is the flow rate $(\mathrm{kg} / \mathrm{s}) ; \mathrm{c}_{\mathrm{pa}}$ is the specific heat capacity at the constant pressure of intake air $(\mathrm{J} / \mathrm{kg} . \mathrm{K}) ; \mathrm{T}_{1}(\mathrm{~K})$ is the ambient temperature (before the compressor); $\mathrm{k}_{\mathrm{a}}$ is the specific heat capacity ratio of intake gas $\left(k_{a}=c_{p a} / c_{v a}\right), \pi_{c}(-)$ is the pressure ratio after and before of compressor $\left(p_{2} / p_{1}\right)$.

\subsubsection{Turbine and Compressor Balance / Ravnoteža turbine i kompresora}

The turbine and compressor are mounted on a common shaft (Figure 4). The power of exhaust gas drives compressor blades, the intake air is compressed from temperature $T_{1}$, pressure $p_{1}$ to temperature $T_{2^{\prime}}$, pressure $p_{2}$. The exhaust gas is expanded from temperature $T_{3^{\prime}}$ pressure $p_{3}$ to temperature $T_{4^{\prime}}$ pressure $p_{4}$ and release the energy. At the steady condition, the power of the turbine and the power of the compressor are equal (with mechanical loss).

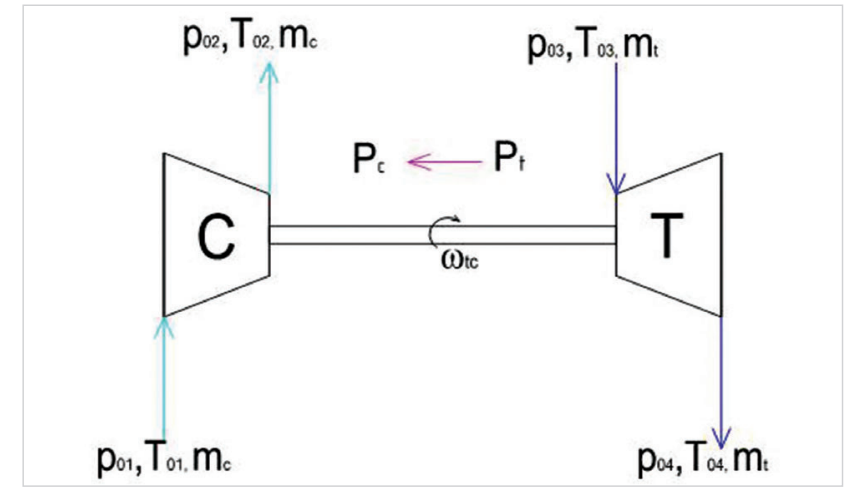

Figure 4 The balance between the turbine and compressor Slika 4. Ravnoteža između turbine i kompresora

The balanced equation of turbine power and compressor power is

$\mathrm{P}_{\mathrm{c}}=\eta_{\mathrm{m}} \mathrm{P}_{\mathrm{t}}$

Where $\eta_{m}$ is the mechanical loss of bearing.

\subsection{Temperature and pressure in the intake and exhaust manifolds / Temperatura i tlak u usisnim i ispušnim razvodnicima}

Model temperature and pressure in the intake and exhaust manifolds based on the law of mass conservation, ideal law, gives as

$$
\frac{\mathrm{d}}{\mathrm{dt}} \mathrm{p}_{\mathrm{im}}=\frac{\mathrm{R}_{\mathrm{a}} \mathrm{T}_{\mathrm{im}}}{\mathrm{V}_{\mathrm{im}}}\left(\dot{\mathrm{m}}_{\mathrm{c}}-\dot{\mathrm{m}}_{\text {in_cyl }_{-}}\right)
$$

Where $\mathrm{p}_{\mathrm{im}}, \mathrm{p}_{\mathrm{em}}$ are the pressure in the intake and exhaust manifolds $\left(\mathrm{N} / \mathrm{m}^{2}\right) ; \mathrm{T}_{\mathrm{im}}, \mathrm{T}_{\mathrm{em}}$ are the temperature in the intake and exhaust manifolds $(K) ; R_{a^{\prime}} R_{e}$ gas constant of intake and exhaust gases $(\mathrm{j} / \mathrm{kg} \cdot \mathrm{K}), \mathrm{V}_{\mathrm{im}}, \mathrm{V}_{\mathrm{em}}$ are the manifold volumes $\left(\mathrm{m}^{3}\right) ; \dot{\mathrm{m}}_{\mathrm{c}^{\prime}} \dot{\mathrm{m}}_{\mathrm{t}}$ are 
Table 1 Diesel engine specifications [15],[16]

Tablica 1. Specifikacije dizelskih motora [15], [16]

\begin{tabular}{|l|c|l|c|}
\multicolumn{1}{|c|}{ Parameters } & Values & \multicolumn{1}{c|}{ Parameters } & Values \\
\hline Bore $\mathrm{x}$ stroke $(\mathrm{mm} \times \mathrm{mm})$ & $105 \times 120$ & Inducer compressor, $\mathrm{mm}$ & 38 \\
\hline Number of cylinders & 6 & Exducer compressor, $\mathrm{mm}$ & 49 \\
\hline Compression ratio & 16.6 & Inducer turbine, $\mathrm{mm}$ & 43 \\
\hline Output Power at nominal, $\mathrm{kW}$ & 105 & Exducer turbine, $\mathrm{mm}$ & 38 \\
\hline Fuel consumption at nominal, g/kWh & 228 & Turbine A/R & 0.61 \\
\hline
\end{tabular}

mass flow through the compressor and turbine $(\mathrm{kg} / \mathrm{s}) ; \dot{\mathrm{m}}_{\mathrm{in} \mathrm{cyl}^{\prime}}$ $\dot{\mathrm{m}}_{\text {out } \_ \text {cyl }}$ are the mass flow in and out the cylinders $(\mathrm{kg} / \mathrm{s}), \dot{\mathrm{m}}_{\text {out cyl }}$ $=\dot{\mathrm{m}}_{\mathrm{in} \_ \text {cyl }}+\dot{\mathrm{m}}_{\mathrm{f}}$, with $\dot{\mathrm{m}}_{\mathrm{f}}$ is the fuel mass flow.

\section{EXPERIMENTAL VALIDATION / Eksperimentalna validacija}

3.1. The object of the experiment / Predmet eksperimenta The D-G used in experiments is Deutz 226B type with turbocharger GT1749V. The technical parameters of the diesel engine are presented in Table 1.

\subsection{Set up the experiments / Postavljanje eksperimenata}

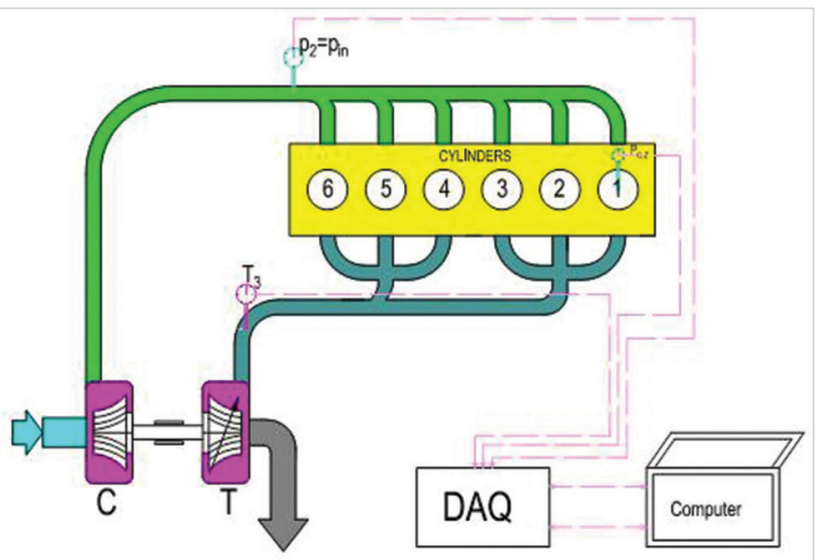

Figure 5 Principle Layout of Experiments

T -Turbine; C -Compressor; DAQ -Data Acquisition; $\mathrm{p}_{2}$ - Intake pressure sensor; $T_{3}$-Exhaust Temperature sensor; $p_{c, z}-i n_{-}$ cylinder pressure sensor.

Slika 5. Glavni izgled eksperimenata

$T$ - turbina; C-kompresor; DAQ - Prikupljanje podataka; 2 senzor tlaka usisa; T3 - senzor temperature ispušnih plinova; $p c$, $z$ - senzor tlaka u incilindru.

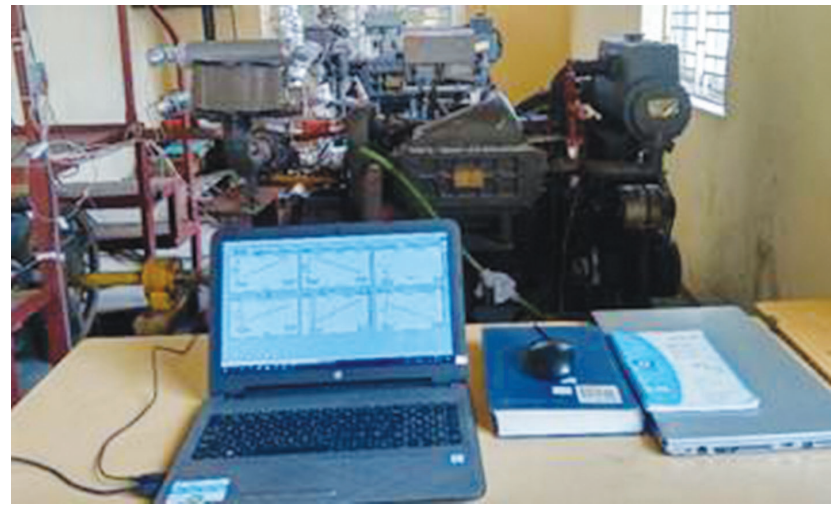

Figure 6 Set up the experiments

Slika 6. Postavljanje eksperimenata

\section{RESULTS / Rezultati}

The experiments were carried out following 2 steps. Step 1: Experiments were done at nominal speed (1500 rpm) with $100 \%$ of the opening degree and differences of load $(0 \%, 25 \%$, $50 \%, 75 \%)$. These experiments were carried out as if there were no VNT turbocharger. The purpose of this step is to evaluate the accuracy of the theoretical model which was built previously. The other purpose is to determine the load conditions which need to adjust the nozzle opening degree. Step 2: Experiments carried out at modes with differences of nozzle opening degree (100\% opening, $90 \%$ opening, $80 \%$ opening) at specific of loads ( $25 \%$ load, $50 \%$ load) at the constant speed, $1500 \mathrm{rpm}$. In each situation, the engine performances were recorded and evaluated.

4.1 The results with VNT $=100 \%$ / Rezultati s VNT $=100 \%$ The experiments were carried out at nominal speed, fully opening nozzle at different loads ( $0 \%$ load $\div 75 \%$ load)

Table 2 The intake pressure before the cylinder (at $n=1500 \mathrm{rpm}$, VNT $=100 \%$ )

Tablica 2. Ulazni tlak prije cilindra (pri $n=1500 \mathrm{o} / \mathrm{min}, \mathrm{VNT}=100 \%)$

\begin{tabular}{|c|c|c|c|}
\hline \multirow{2}{*}{ Load regime } & \multicolumn{3}{|c|}{ Intake turbine pressure, $\mathrm{p} 2$ (bar) } \\
\hline & Measured & Simulated & Error (\%) \\
\hline $75 \%$ & 1.589 & 1.6785 & 5.6 \\
\hline $50 \%$ & 1.32 & 1.38 & 4.5 \\
\hline $25 \%$ & 1.000 & 1.040 & 4.0 \\
\hline $0 \%$ & 0.996 & 1.022 & 2.6 \\
\hline
\end{tabular}

Table 3 Exhaust temperature before the cylinder ( $\mathrm{n}=1500 \mathrm{rpm}$,

$$
\text { VNT }=100 \% \text { ) }
$$

Tablica 3. Temperatura ispušnih plinova prije cilindra $(n=1500 \mathrm{o} /$ $\min , V N T=100 \%$ )

\begin{tabular}{|c|c|c|c|}
\hline \multirow{2}{*}{ Load regime } & \multicolumn{3}{|c|}{ Exhaust Temperature before the cylinder, T3 ('K) } \\
\hline $75 \%$ & Measured & Simulated & Error (\%) \\
\hline $50 \%$ & 740 & 750 & 1.3 \\
\hline $25 \%$ & 655 & 703.6 & 2.1 \\
\hline $0 \%$ & 470 & 641 & 2.1 \\
\hline
\end{tabular}

From the results, the gaps of parameters (intake pressures and exhaust temperatures) between the simulation and measurement were below $6 \%$, so that this modelling can be acceptable and use it for the next steps. Besides that, the results showed that the intake pressure at low load ( $\leq 50 \%$ load) was low, which was the basis of adjusting the nozzle opening degree. In the below parts, the experiments were carried out at differences in the nozzle opening degree $(100 \%, 90 \%, 80 \%)$. 


\subsection{The results at load of $25 \%$ / Rezultati pri opterećenju od $25 \%$}

4.2.1. Intake pressure and exhaust temperature / Ulazni tlak i temperatura ispuha

The experiment results of intake pressure are presented in Table 4.

Table 4 Intake pressure $\mathrm{p}_{2}$ (bar) at $\mathrm{n}=1500 \mathrm{rpm}$, load $25 \%$ Tablica 4. Ulazni tlak $p_{2}$ (bar) pri $n=1500$ o / min, opterećenje $25 \%$ Nozzle opening, \% Measured, bar Simulation, bar error (\%)

\begin{tabular}{|c|c|c|c|}
\hline $100 \%$ & 1.00 & 1.04 & 4.0 \\
\hline $90 \%$ & 1.21 & 1.16 & 4.1 \\
\hline $80 \%$ & 1.38 & 1.32 & 4.3 \\
\hline
\end{tabular}

Table 4 shows that when the nozzle opening degree reduced by $10 \%, 20 \%$, the intake pressure increased by 0.21 bar (21\%), 0.38 bar (38\%), respectively. Besides that, other engine characteristics also improved.

The exhaust temperature was recorded as in Table 5.

Table 5 The exhaust temperature at $\mathrm{n}=1500 \mathrm{rpm}$, load $25 \%$ Tablica 5. Temperatura ispušnih plinova pri $n=1500 \mathrm{o} / \mathrm{min}$, opterećenje $25 \%$

\begin{tabular}{|c|c|c|c|}
\hline \multirow{2}{*}{$\begin{array}{c}\text { Nozzle opening } \\
\text { degree }\end{array}$} & \multicolumn{3}{|c|}{ Exhaust temperature (K) } \\
\hline $100 \%$ & 655 & 641 & $2.1 \%$ \\
\hline $90 \%$ & 625 & 615 & $3.2 \%$ \\
\hline $80 \%$ & 612 & 605 & $2.3 \%$ \\
\hline
\end{tabular}

With the load $25 \%$, the exhaust temperature reduced $30^{\circ} \mathrm{K}$, $43^{\circ} \mathrm{K}$ corresponding with the opening degree reduced $10 \%$, $20 \%$, respectively (measured values)

\subsubsection{Specific fuel consumption and brake power / Specifična} potrošnja goriva i snaga kočnice

The in_cylinder pressure characteristic was simulated corresponding to the nozzle opening degrees (100\%, 90\%, $80 \%$ ) at $25 \%$ load as in Figure 7.

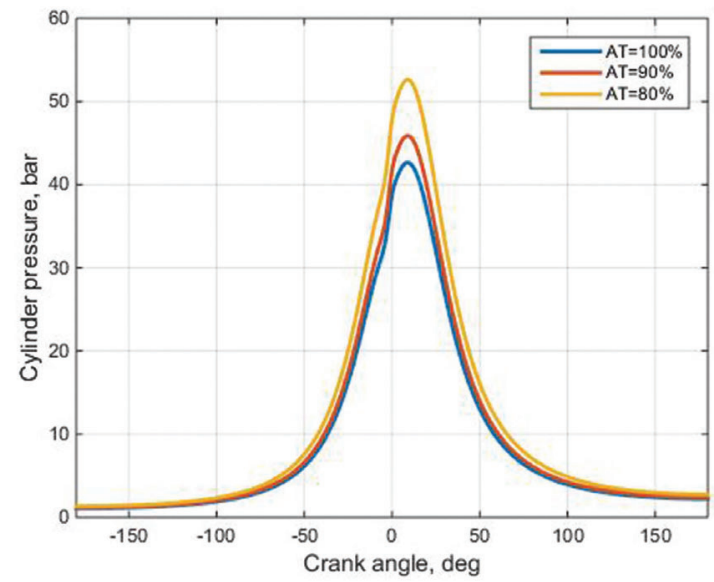

Figure 7 In-cylinder pressure simulation corresponding to nozzle opening degree at load of $25 \%, 1500 \mathrm{rpm}$

Slika 7. Simulacija tlaka u cilindru koja odgovara stupnju otvaranja mlaznica pri opterećenju od 25\%, 1500 o / min

At the constant load (25\%) and speed (1500 rev/min), the specific fuel consumption and brake power were recorded with differences nozzle opening (Table 6).
Table 6 Specific fuel consumption at $\mathrm{n}=1500 \mathrm{rpm}$, load $25 \%$ Tablica 6. Specifična potrošnja goriva pri $n=1500 \mathrm{o} / \mathrm{min}$, opterećenje $25 \%$

\begin{tabular}{|c|c|c|c|c|c|c|c|}
\hline $\begin{array}{c}\text { Nozzle } \\
\text { opening } \\
\text { degree }\end{array}$ & $\begin{array}{c}\text { Specific fuel consumption } \\
\text { Measured } \\
\text { g/kW.h }\end{array}$ & $\begin{array}{c}\text { Simulation } \\
\text { g/kW.h }\end{array}$ & $\begin{array}{c}\text { error } \\
\text { (\%) }\end{array}$ & $\begin{array}{c}\text { Measured } \\
\text { kW }\end{array}$ & $\begin{array}{c}\text { Simulation } \\
\text { kW }\end{array}$ & error (\%) \\
\hline $100 \%$ & 295 & 285 & $3.4 \%$ & 19.3 & 20 & $3.6 \%$ \\
\hline $90 \%$ & 280 & 275 & $2.8 \%$ & 20.1 & 21 & $4.4 \%$ \\
\hline $80 \%$ & 278 & 268 & $3.6 \%$ & 21.6 & 22.5 & $4.2 \%$ \\
\hline
\end{tabular}

4.2.3. The evaluation of the changing nozzle opening degree at load of $25 \%$ / Procjena promjene stupnja otvaranja mlaznica pri opterećenju od $25 \%$

The below table result (Table 7) shows the effectiveness of narrower nozzle opening, the specific fuel consumption and brake power improved while the nozzle opening was decreased.

Table 7 The evaluation of the changing nozzle opening degree at load of $25 \%$ (measured values)

Tablica 7. Procjena promjene stupnja otvaranja mlaznica pri opterećenju od 25\% (izmjerene vrijednosti)

\begin{tabular}{|c|c|c|c|c|}
\hline $\begin{array}{c}\text { Nozzle } \\
\text { opening } \\
\text { degree }\end{array}$ & \multicolumn{2}{|c|}{$\begin{array}{c}\text { Changing } \\
\text { Specific fuel consumption }\end{array}$} & \multicolumn{2}{c|}{$\begin{array}{c}\text { Changing } \\
\text { Brake power }\end{array}$} \\
\hline $100 \%$ & $\mathrm{~g} / \mathrm{kW} . \mathrm{h}$ & $(\%)$ & $\mathrm{kW}$ & $(\%)$ \\
\hline $90 \%$ & - & - & - & - \\
\hline $80 \%$ & -15 & -5 & +0.8 & $+4 \%$ \\
\hline
\end{tabular}

Table 7 shows the effectiveness when the opening degree reduced by $10 \%$, the specific fuel consumption reduced $15 \mathrm{~g} /$ kW.h and the brake power increased by $4 \%$. when the opening degree reduced by $20 \%$, the specific fuel consumption reduced by $17 \mathrm{~g} / \mathrm{kW} . \mathrm{h}$ and the brake power increased by $11 \%$.

\subsection{The results at load of $50 \%$ / Rezultati pri opterećenju od $50 \%$}

4.3.1. Intake pressure and exhaust temperature / Ulazni tlak $i$ temperatura ispuha

The experiment results of intake pressure are presented in Table 8.

Table 8 Intake pressure $\mathrm{p}_{2}(\mathrm{bar})$ at $\mathrm{n}=1500 \mathrm{rpm}$, load $50 \%$ Tablica 8. Ulazni tlakp2 (bar) pri $n=1500$ o $/ \mathrm{min}$, opterećenje $50 \%$

\begin{tabular}{|c|c|c|c|}
\hline Nozzle opening, \% & Measured, bar & Simulation, bar & error (\%) \\
\hline $100 \%$ & 1.32 & 1.38 & 4.5 \\
\hline $90 \%$ & 1.38 & 1.41 & 2.2 \\
\hline $80 \%$ & 1.42 & 1.45 & 2.1 \\
\hline
\end{tabular}

Table 8 shows that when the nozzle opening degree reduced by $10 \%, 20 \%$, the intake pressure increased by 0.06 bar $(4.5 \%)$, 0.1 bar $(7.6 \%)$, respectively. It is not as high as the previous one ( $25 \%$ load), the engine performances also improved as the below results.

The exhaust temperature was shown in Table 9.

Table 9 The exhaust temperature at $\mathrm{n}=1500 \mathrm{rpm}$, load $50 \%$ Tablica 9. Temperatura ispušnih plinova pri $n=1500 \mathrm{o} / \mathrm{min}$, opterećenje 50\%

\begin{tabular}{|c|c|c|c|}
\hline \multirow{2}{*}{$\begin{array}{c}\text { Nozzle opening } \\
\text { degree }\end{array}$} & \multicolumn{3}{|c|}{ Exhaust temperature (K) } \\
\hline $100 \%$ & 725 & 705 & 2.8 \\
\hline $90 \%$ & 716 & 698 & 2.5 \\
\hline $80 \%$ & 708 & 690 & 2.5 \\
\hline
\end{tabular}


With load 50\%, the exhaust temperature was not changed much, only reduced $9^{\circ} \mathrm{K}, 17^{\circ} \mathrm{K}$ corresponding with the opening degree reduced by $10 \%, 20 \%$, respectively (measured values).

\subsubsection{Specific fuel consumption and brake power / Specifična potrošnja goriva i snaga kočnice}

The in_cylinder pressure characteristic was simulated corresponding to the nozzle opening degrees as in Figure 8.

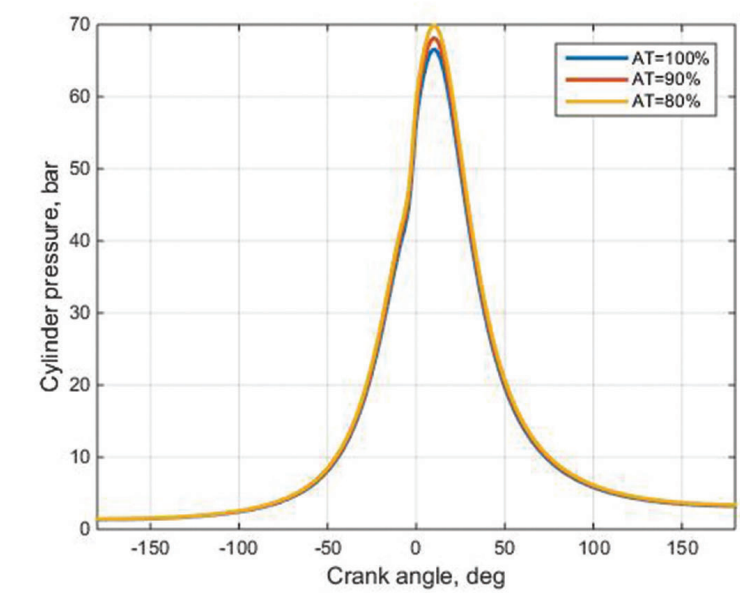

Figure 8 In-cylinder pressure simulation corresponding to nozzle opening degree at load of 50\%, $1500 \mathrm{rpm}$

Slika 8. Simulacija tlaka u cilindru koja odgovara stupnju otvaranja mlaznica pri opterećenju od 50\%, 1500 o / min

At the constant load (50\%) and speed (1500 rev/min), the specific fuel consumption and brake power were recorded with differences in nozzle opening (Table 10).

Table 10 Specific fuel consumption at $\mathrm{n}=1500 \mathrm{rpm}$, load of $50 \%$ Tablica 10. Specifična potrošnja goriva pri $n=1500 \mathrm{o} / \mathrm{min}$, opterećenje od $50 \%$

\begin{tabular}{|c|c|c|c|c|c|c|c|}
\hline $\begin{array}{c}\text { Nozzle } \\
\text { opening } \\
\text { degree }\end{array}$ & \multicolumn{3}{|c|}{$\begin{array}{c}\text { Specific fuel consumption, } \\
\text { g/kW.h }\end{array}$} & \multicolumn{3}{c|}{ Brake power,kW } \\
\hline & g/kW.h & $\begin{array}{c}\text { Simulation } \\
\text { g/kW.h }\end{array}$ & $\begin{array}{c}\text { Error } \\
(\%)\end{array}$ & $\begin{array}{c}\text { Measured } \\
\text { kW }\end{array}$ & $\begin{array}{c}\text { Simulation } \\
\text { kW }\end{array}$ & $\begin{array}{c}\text { Error } \\
(\%)\end{array}$ \\
\hline $100 \%$ & 278 & 284 & 2.2 & 40.1 & 41.3 & 3.0 \\
\hline $90 \%$ & 272 & 278 & 2.2 & 41.3 & 42.3 & 2.4 \\
\hline $80 \%$ & 266 & 273 & 2.6 & 42.5 & 43.4 & 2.1 \\
\hline
\end{tabular}

4.3.3. The evaluation of the changing nozzle opening degree at the load of $50 \%$ / Procjena promjene stupnja otvaranja mlaznica pri opterećenju od $50 \%$

Similarly with the above case (load of $25 \%$ ), The result in Table 11 shows the effectiveness of narrower nozzle opening.

Table 11 The evaluation of the changing nozzle opening degree at the load of $50 \%$

Tablica 11. Procjena promjene stupnja otvaranja mlaznica pri opterećenju od $50 \%$

\begin{tabular}{|c|c|c|c|c|}
\hline \multirow{2}{*}{$\begin{array}{c}\text { Nozzle } \\
\text { opening, \% }\end{array}$} & \multicolumn{2}{|c|}{ Changing } & \multicolumn{3}{c|}{ Changing } \\
\hline & Specific fuel consumption & \multicolumn{2}{c|}{ Brake power } \\
\hline $100 \%$ & - & - & - & - \\
\hline $90 \%$ & -6 & -2.1 & +1.3 & +3.2 \\
\hline $80 \%$ & -12 & -4.2 & +1.5 & +3.7 \\
\hline
\end{tabular}

Table 11 shows the effectiveness when the opening degree is reduced by $10 \%$, the specific fuel consumption reduced by $6 \mathrm{~g} /$
kW.h and the brake power increased by $3.2 \%$. when the opening degree is reduced by $20 \%$, the specific fuel consumption is reduced by $12 \mathrm{~g} / \mathrm{kW}$.h and the brake power increased by $3.7 \%$

General evaluation: The errors between the measurements at the laboratory and the simulation were $<6 \%$, which is acceptable. Therefore, the modelling can be used to simulate the engine thermodynamic characteristics. Besides that, the measures and simulation show that when the nozzle opening degree was reduced $(10 \%-20 \%)$ the engine performances significantly improved as described in Table 4\%Table 11.

\section{CONCLUSION / Zaključak}

Experiments on a marine diesel generator engine with VNT turbocharger were carried out to prove the effectiveness of integration theoretical study and experimental study. The received data from both experiments and the simulation showed that at the low load regimes $(0 \div 50 \%$ load) the controlled narrowing nozzle opening degree (narrowed $10 \div 20 \%$ ) could improve the diesel performances. The intake pressure increased by 0.21 bar $\div 0.38$ bar corresponding to $25 \%$ load, by 0.06 bar $\div 0.1$ bar corresponding to $50 \%$ load. The specific fuel consumption significantly reduced ( $5 \% \div 5.7 \%$ with $25 \%$ load, $2.1 \% \div 4.2 \%$ with $50 \%$ ). The brake power improved ( $4 \% \div 11 \%$ for $25 \%$ load, $3.2 \% \div 3.7 \%$ for $50 \%$ load). It may be a basis to improve the old engine with the fixed turbocharger by replacing a new one with VNT turbocharger, which can be applied to the Viet Nam ship fleets.

\section{Acknowledgment / Zahvala}

We would like to thank the Maritime Institute of Ho Chi Minh City University of Transport (UT) and Research and Development Institute of Viet Nam Marine University (VMU) for very helpful support to carry out this research.

\section{REFERENCES / Literatura}

[1] Watson, N. and M. Janota, Turbocharging the internal combustion engine. London and Basingstoke:THE MACMILLAN PRESS LTD. (1982).

[2] Benson, R.S. and N.D. Whitehouse, Internal Combustion Engines. Elsevier Science \& Technology Books. (1984).

[3] Heywood, J.B., Internal combustion engine fundamentals. New York : McGraw-Hill. (1988).

[4] Miyamoto, N., et al., Description and analysis of diesel engine rate of combustion and performance using Wiebe's functions. SAE Technical Paper (1985).https://doi. org/10.4271/850107

[5] Woschni, G., A universally applicable equation for the instantaneous heat transfer coefficient in the internal combustion engine. SAE Technical paper (1967). https://doi. org/10.4271/670931

[6] Ferguson, C.R. and A.T. Kirkpatrick, Internal combustion engines: applied thermosciences. John Wiley \& Sons. (2015).

[7] Franklin, P.J.S.T., Performance development of the holset variable geometry turbocharger. p. 1189-1201. (1989). https://doi.org/10.4271/890646

[8] Eriksson, L. and L. Nielsen, Modeling and control of engines and drivelines. John Wiley \& Sons. (2014)

[9] Jinnai, Y., et al., A variable geometry (VG) turbochargerfor passenger Cars to Meet European Union emission regulations. 49(2): p. 17-26. (2012).

[10] Weibe, I., Semi-empirical expression for combustion rate in engines, in Proceedings of Conference on piston engines, USSR Academy of sciences, Moscow. USSR Academy of sciences, Moscow. p. 185-191 (1956).

[11] Wahlström, J. and L. Eriksson, Modelling diesel engines with a variable-geometry turbocharger and exhaust gas recirculation by optimization of model parameters for capturing non-linear system dynamics. Proceedings of the Institution of Mechanical Engineers, Part D: Journal of Automobile Engineering. 225(7): p. 960-986. (2011). https://doi.org/10.1177/0954407011398177

[12] Wahlström, J., Control of EGR and VGT for emission control and pumping workminimization in diesel engines. Institutionen för systemteknik (2006).

[13] Nguyen-Schäfer, H., Thermodynamics of Turbochargers, in Rotordynamics of Automotive Turbochargers. 2015, Springer. p. 21-36. https://doi.org/10.1007/978-3-31917644-4_2

[14] Sorenson, S.C., et al., Compact and accurate turbocharger modelling for engine control. p. 1343-1353. (2005)

[15] Deutz, Deutz Engine TD226B Specifications, (2015).

[16] Garrett, GT 1749V specifications. Honeywell Garrett (2019). 